\title{
De creativiteit in de wereld en de werkelijkheid van God. De theologie van Gordon Kaufman in betrekking tot Wilhelm Herrmann en Rudolf Bultmann
}

\begin{abstract}
Author:
Rick Benjamins ${ }^{1,2}$

Affiliations:

${ }^{1}$ Protestant Theological University (PThU),

Amsterdam/Groningen,

the Netherlands \& Faculty of Theology and Religious Studies, University of Groningen, the Netherlands

${ }^{2}$ Department of Systematic Theology and Christian Ethics, University of Pretoria, South Africa

Note:

Prof. Dr. Rick Benjamins is participating as research fellow of Prof. Dr Danie Veldsman, Faculty of Theology at the University of Pretoria, South Africa. This article represents a reworked version of a paper read at an Expert Seminar on 'Anthropology in an Age of Science' with scholars in Systematic Theology of the Protestant Theological University and the Faculty of Theology of the University of Pretoria (on 08 September 2011 in Pretoria).
\end{abstract}

Correspondence to: Rick Benjamins

Email:

hsbenjamins@pthu.nl

Postal address:

Herbergier 11, 6641 DT

Beuningen, the Netherlands

Dates:

Received: 22 Jan. 2013

Accepted: 12 Apr. 2013

Published: 07 June 2013

Read online:
The creativity in the world and the reality of God. The theology of Gordon Kaufman in relation to Wilhelm Herrmann and Rudolf Bultmann. The article aims to defend the compatibility of Kaufman's concept of a world grounded on immanent creativity and Bultmann's concept of God who addresses us in the proclamation of the cross. Since Darwin's natural selection it is hard to conceive of a universe that is designed and allows for the assumption of a creator. Theologians have grappled with the meaning of nature and history from the time their purposiveness was contested. Wilhelm Herrmann argued that we undergo a transforming goodness in our experiences of Jesus' inner life which makes us confess that the goodness of a hidden God determines the world and makes us contribute to its development. We cannot prove the influence of God's goodness, but we can experience it personally. Rudolf Bultmann radically changed this perspective. He argued that we are not placed in a meaningful world on behalf of Jesus' inner life; instead, the proclamation of the cross liberates us from any worldview in order to live authentically. Gordon Kaufman proposes an understanding of God as the creativity in the world and its evolution without any dualism or supernaturalism. He denies a blueprint for creation but accepts a serendipitous creativity that can function as the basis for the articulation of our worldview and our orientation in the world. According to Kaufman, Bultmann still retains the dualistic presupposition of the traditional understanding of God. This article argues that the differences between Kaufman and Bultmann are limited, for whereas Bultmannn underlines the reality of God who addresses us in the proclamation of the cross and thereby recreates us, Kaufman wants to construct a worldview grounded on creativity. The creativity in the world and God's (re)creative acts are not incompatible.

\section{Inleiding}

De opvattingen van Darwin hebben grote gevolgen gehad voor ons denken over de natuur en dientengevolge ook voor die theologie die zich van de natuurwetenschappen rekenschap wil geven (Smedes 2009). Door de introductie van de natuurlijke selectie als principe van de evolutie waren er geen doeloorzaken meer nodig om het functioneren van de natuur te verklaren. Daarmee werd de doodsteek gegeven aan die vorm van natuurlijke theologie die aannam dat de natuur werkt volgens een plan, en uit het plan voor de schepping een schepper afleidde. Aan de schijnbaar doelmatige organisatie van de wereld ligt door de natuurlijke selectie slechts een immanent en natuurlijk proces ten grondslag. Deze opvatting heeft de christelijke theologie voor belangrijke vragen gesteld, omdat ze suggereert dat de natuur een product is van het toeval en geen bedoelde schepping. Ze heeft bovendien in de hand gewerkt dat mentale processen, bewustzijnsinhouden, ethische waarden of godsdienstige voorstellingen op een reductionistische manier werden gezien als alleen maar bijverschijnselen van een materiële ontwikkeling.

Van meet af aan is Darwins theorie door theologen verschillend ontvangen (Leeuwenburgh 2009). In theologische beschouwingen uit de 19e eeuw stond vooral het vraagstuk van het wonder centraal, omdat de werkelijkheid van God en de mogelijkheid van zijn directe ingrijpen in de natuur daardoor werden gethematiseerd. In Nederland verdedigde A.T. Reitsma de mogelijkheid van het wonder en Gods directe bemoeienis met de natuur die volgens hem niet werden uitgesloten door Darwins theorie (Leeuwenburgh 2009:85-96). De moderne theologen zagen in Darwin juist een medestander in hun verzet tegen het supranaturalisme en de opvatting dat God de natuurwetmatigheid zou doorbreken (Leeuwenburgh 2009:69-76). J.H. Scholten meende dat God niet van buitenaf in de wereld ingrijpt, maar immanent werkzaam is in de natuur en de geschiedenis om haar door de natuurwetmatigheid te leiden naar een hoger zedelijk plan (Benjamins 2008:61-63). Scholten veronderstelde daarmee dat de natuurwetmatigheid zelf doelgericht is. C.W. Opzoomer was daarin voorzichtiger. Wij kunnen wetenschappelijk niet

How to cite this article: Benjamins, R., 2013, 'De creativiteit in de wereld en de werkelijkheid van God. De theologie van Gordon Kaufman in betrekking tot Wilhelm Herrmann en Rudolf Bultmann', HTS Teologiese Studies/Theological Studies 69(1), Art. \#1925, 9 pages. http:// dx.doi.org/10.4102/hts.v69i1.1925

Copyright: @ 2013. The Authors. Licensee: AOSIS OpenJournals. This work is licensed under the Creative Commons Attribution License. 
zeggen dat de orde van de natuur doelgericht is, maar zijn op grond van ons gevoel zeker van Gods bestaan en kunnen de wereld daarom ook religieus beschouwen als een geordend geheel (Benjamins 2008:69-70). Een onverkorte overname van Darwins opvattingen was daarmee voor geen van deze theologen mogelijk, omdat ze ofwel verdedigden dat God door wonderen in de natuur ingrijpt, ofwel geloofden dat de gesloten natuurwetmatigheid zelf doelgericht is, ofwel geloofden in een beschouwingswijze van doelgerichtheid die natuurwetenschappelijk weliswaar niet kan worden bewezen, maar ook niet ontkracht.

Het is begrijpelijk dat theologen de opvatting van de doelmatigheid niet los wilden laten vanwege de overtuiging dat deze wereld als schepping een doel heeft. Het bleek ook wel mogelijk om de evolutietheorie te verenigen met de gedachte van doelgerichtheid. De geldigheid van de biologische evolutietheorie moet dan strikt worden beperkt tot de manier waarop de natuur werkt, en de doelgerichtheid moet worden aangeleverd door het kader waarin wij de natuur beschouwen. De doelgerichtheid kan dan empirisch weliswaar niet worden vastgesteld, maar wetenschappelijk evenmin worden uitgesloten en is niet langer een natuurwetenschappelijke opvatting, maar een geloofsvoorstelling (Haught 2000, 2007; Peters \& Hewlett 2003). Hoewel er tegen die argumentatie formeel weinig ingebracht kan worden, is het compromis toch ongemakkelijk, omdat de doelmatigheid een geloofsopvatting wordt die niet uit de werkelijkheid wordt afgeleid, maar daarin wordt ingelezen. Deze opvatting ontwijkt naar mijn idee ook de meest prikkelende gedachte die met de evolutietheorie is verbonden, namelijk dat er uit een chaotische toestand een orde kan ontstaan die niet berust op toeval maar evenmin op het ontwerp van een ontwerper.

De natuur beschikt kennelijk over een mechanisme om op een blinde en niet-doelgerichte wijze ogenschijnlijke vormen van ontwerp te produceren. Op een mooie manier heeft Hans Jonas dit wonder van de natuur na Darwin in zijn filosofische biologie onder woorden gebracht (Jonas 1994). Voor de vroegste mensheid was alles levend en bezield en woonde er zelfs een kracht in levenloze dingen. Een latere traditie onderscheidde echter tussen lichaam en ziel. Daarmee erkende het een onbezield, strikt materieel stuk van de werkelijkheid, maar bleef een volstrekt materialisme onmogelijk, omdat de ziel haar eigen werkelijkheid ook in deze wereld bezit. ${ }^{1} \mathrm{Na}$ Darwin werd het echter mogelijk om geheel materialistisch te denken. Ziel, geest, bewustzijn en denken zijn uit de ongeleide ontwikkeling van de materie opgekomen en behoren niet tot een andere orde. Opmerkelijk genoeg geeft juist deze materialistische opvatting aan de natuur een nieuwe glans, want materie moet wel iets bijzonders zijn, dat daaruit leven, bewustzijn en geest tevoorschijn kunnen komen. Op hetzelfde moment dat aan de natuur doelgerichtheid volgens een onderliggend ontwerp door een ontwerper wordt ontzegd, krijgt ze iets wonderlijks

1.Met denkers als Plotinus en Augustinus werd vooral het zielenleven en zijn diepte onderzocht. Bij Descartes wordt de ziel nog gezien als het uitzonderingsgebied van de res cogitans in de res extensa van de materie, maar na Darwin werd deze opvatting overbodig. terug, omdat ze het vermogen heeft orde en denken voort te brengen alsof ze daar op uit was (Jonas 1994:99-101).

Meer dan andere theologen maakte Gordon Kaufman de daarmee aangeduide creativiteit van de natuur in de laatste twee decennia tot uitgangspunt van zijn denken. Hij beschrijft de kern van zijn theologische programma als volgt:

Instead of continuing to imagine God as The Creator, a kind of personlike reality who has brought everything into being, I have for some years been developing and elaborating a conception of God as simply the creativity that has brought forth the world and all its contents, from the Big Bang all the way down to the present. (Kaufman 2006: ix)

Kaufman presenteert hiermee een reconstructie van God en een revisie van doelmatigheid, gebaseerd op de creativiteit die in de evolutie opgesloten ligt, waarmee hij ieder dualisme en supranaturalisme wil vermijden. Zijn herformulering van het christelijk geloof vraagt om een doordenking waaraan ik hier wil bijdragen. Ik doe dat door hem te vergelijken met Wilhelm Herrmann en Rudolf Bultmann die in hun eigen tijd al evenzeer probeerden om aan te sluiten bij het moderne wereldbeeld, maar toch niet prijs wilden geven wat Kaufman - zelfs expliciet tegen Bultmann - los laat.

\section{Wilhelm Herrmann}

Met Wilhelm Herrmann komen wij middenin de theologie van de 19e eeuw terecht. Zijn denken bevindt zich in het spoor van Albrecht Ritschl in een Kantiaans kader waarin veel gedachten van Luther en Schleiermacher doorklinken. Hoewel zijn theologie vooral nog wordt bestudeerd vanwege haar invloed op Barth en Bultmannn, verdient zij meer dan alleen maar antiquarische aandacht (Berkhof 1985; Chalamet 2005). Centraal staat bij hem de gedachte dat wij persoon kunnen worden als wij door het innere Leben Jesu omgang vinden met God. In die omgang verstaan wij dat de werkelijkheid wordt bepaald door God, die de macht van het goede is. Omdat de goedheid van God de wereld bepaalt, leert het geloof ons de doelmatigheid van deze wereld zien. Tot dit inzicht kan de wetenschap niet komen en het is, zo stelt Herrmann in zijn favoriete termen, dan ook niet bewijsbaar, maar voor het geloof wel ervaarbaar. Een teleologische beschouwing van de wereld, die na Darwin door de wetenschappen buiten de deur werd gezet, vormt volgens Herrmann de voltooiing van het geloof. Om dat goed te belichten is een korte uiteenzetting nodig in drie stappen: van (1) de persoon naar (2) de omgang met God door het innerlijke leven van Jezus, die ons (3) brengt tot het inzicht van God als de bepalende macht van het goede.

Volgens Herrmann worden wij pas persoon als wij door de zedelijkheid overwinnen wat ons van nature is gegeven. Als natuurwezens zijn wij bepaald door allerlei driften, strevingen en neigingen, maar daarvan maken wij ons los als wij onszelf zedelijke doelen stellen, die niet van de natuur afkomstig zijn en van onze natuurlijke gerichtheid kunnen afwijken (Herrmann [1901] 1904:27-44). Dat is Kantiaans gedacht. Meer dan Kant legt Herrmann echter nadruk op de ontwikkeling van de zedelijkheid die niet zoals de zedenwet 
bij Kant uit de hemel komt vallen, maar groeit in een gemeenschap en begint met het vertrouwen dat wij in anderen leren hebben. Als wij iemand vertrouwen, geloven wij dat hij zich niet laat regeren door willekeur, natuurlijke aandriften of wisselende omstandigheden - wat hem juist onbetrouwbaar zou maken - maar vasthoudt aan zijn eigen gedrag dat wordt bepaald door normen en waarden. De normen en waarden, waardoor de ander zich laat leiden, worden door die ander realiteiten voor ons, waaraan wij zelf ook willen voldoen door betrouwbaar te zijn. Zo ontstaat er een zedelijke verhouding waarin wij elkaar een wil toevertrouwen die is gericht op overstijgende waarden en niet op eigenbelang. Daardoor wordt gemeenschap mogelijk, omdat wij in de gerichtheid op overstijgende waarden innerlijk met elkaar verbonden zijn terwijl het eigenbelang ons alleen maar van elkaar scheidt. In de zedelijke verhouding leren wij niet alleen om onze uiterlijke handelingen te reguleren, maar komen we ook van binnenuit tot een begrip van wat ons geboden is en waaraan we ons willen houden, zodat we besef krijgen van de zedenwet, die volgens Kant dan wel een onafhankelijke en voorafgaande geldigheid mag hebben, maar die wij pas achteraf uit de vertrouwensrelatie leren kennen (ibid:44-59).

De persoon die zedelijk handelt, roept bij ons eerbied en vertrouwen op en bemiddelt voor ons de ervaring van een transcendente, niet natuurlijke, zedelijke werkelijkheid. Ons vertrouwen in de macht van die werkelijkheid wordt echter voortdurend aangevochten door andermans onbetrouwbaarheid en ons eigen falen, waaruit blijkt dat mensen dikwijls helemaal niet door die zedelijke macht worden bepaald. Daardoor is er alle reden om aan het gehalte, de invloed of de kracht van die transcendente, zedelijke werkelijkheid te vertwijfelen (Herrmann [1901] 1904:117-119). De Christus van het Nieuwe Testament maakt ons in die situatie echter onbetwijfelbaar zeker van God als werkzame zedelijke macht. Die zekerheid is volgens Herrmann niet afkomstig van de uiterlijkheden van Jezus' leven die historisch kritisch kunnen worden onderzocht en ter discussie gesteld kunnen worden, maar van het beeld van Jezus' innerlijke leven dat ons wordt overgeleverd door de mensen die er zelf de bevrijdende werking van hebben ondergaan (Herrmann [1886] 1921:55-66). Als wij door het beeld van zijn innerlijke leven worden gegrepen, staat Jezus voor ons en komt God daaruit tevoorschijn (ibid:77-79). Jezus heeft zelf volstrekt en onwankelbaar geloofd in een goede macht over alle dingen. Hij kon daarmee zo op mensen inwerken dat ze zelf in staat waren tot een leven in kracht met de innigheid van Gods nabijheid. In dat licht kon Jezus zelfs zijn eigen ondergang bezien als een overwinning op het kwade in de macht van het goede. De macht van God die een werkelijkheid is voor Jezus wordt door ons contact met zijn innerlijke leven ook een werkelijkheid voor ons die ons vervult van eerbied en vertrouwen, waardoor wij zelf ook met de macht van God kunnen verkeren (ibid:67-77).

Door het innerlijke leven van Jezus wordt God een werkelijkheid voor ons en komen wij tot omgang met God, waardoor wij als het ware worden losgemaakt van onze natuurlijke werkelijkheid. Herrmann beschrijft die losmaking in theologische termen als onze rechtvaardiging, waarvoor hij gebruik maakt van Ritschls rechtvaardigingsleer. Wij weten dat wij ons dikwijls niet door de macht van het goede laten bepalen en dat is onze zonde. Ondanks onze zonde, die ons van het goede scheidt, leren wij God door Jezus toch kennen als een liefdevolle God die ons vergeeft en daardoor de scheiding tussen ons en hem opheft. Als wij door Jezus met God in contact komen, worden wij ons van onze schuld bewust, maar verdwijnt ons schuldgevoel ook direct zodra het opkomt, omdat wij ons door Gods liefde vergeven weten. Daardoor kunnen wij met God verkeren, die ons nu gaat bepalen en inschakelt bij de realisering van het goede. De macht die met Jezus is, vergeeft door hem onze zonden, aanvaardt ons en transformeert ons daardoor, zodat wij worden ingeschakeld bij de werkingsmacht die zij in deze wereld uitoefent (Herrmann [1886] 1921:80 e.v.).

Door de rechtvaardiging ervaren wij aan onszelf hoe wij, als natuurlijke werkelijkheid die God tegenstreeft, door hem worden omgezet, waardoor zijn macht de bepalende macht over onze werkelijkheid blijkt te zijn. Die ervaring doen wij alleen op als wij ten eerste persoon willen worden en ons in de zedelijke daad onderwerpen aan het goede waaraan wij ons verplicht weten. Ze wordt vervolgens een werkelijkheid voor ons als wij door het innerlijke leven van Jezus met God in contact komen die ons losmaakt, omkeert en transformeert. De opvatting dat God de bepalende macht over deze werkelijkheid is, is dus gebonden aan onze persoonlijke ervaring, maar op grond daarvan komen wij toch tot het algemeen geldige inzicht dat God als macht van het goede de bepalende macht in de wereld is.

Tot dat inzicht komen wij door een paradox (Herrmann [1901] 1904:90-96). De macht van het goede wordt door Jezus een realiteit voor ons die ons losmaakt van de wereld om vervolgens ten goede op de wereld in te werken. Tegelijkertijd zijn wij echter geen moment uitgezonderd van de causaliteit die in de wereldwerkelijkheid werkzaam is. Wij zijn in het geloof losgemaakt van de wereld, terwijl we tegelijkertijd ingevoegd blijven in de wereldse samenhang waarvan we integraal deel uitmaken. Die paradox valt niet op te heffen door één van beide inzichten op te geven. We kunnen de paradoxale inzichten echter wel verenigen in de gedachte dat het goede, dat mij in zijn macht heeft genomen, ook de macht is die nu al versluierd in de werkelijkheid werkt. Wij beleven de macht van het goede tegenover de wereld, maar omdat wij in ons contact met die macht nooit uit de wereldsamenhang en haar causaliteit worden weggenomen, concluderen we dat de macht van het goede ook de macht moet zijn die in deze wereld regeert. De macht van het goede die op mij inwerkt door de Erlebnis van de Tatsache Jezus geeft ons daardoor een nieuwe kijk op de werkelijkheid als een werkelijkheid waarin het goede door Gods inwerking de bepalende macht blijkt te zijn. De religieuze ervaring door het innerlijke leven van Jezus geeft ons het inzicht dat wij zijn opgenomen in een samenhangende groei van het goede. ${ }^{2}$

2.Daarmee voegt Herrmann opvattingen van Kant en Schleiermacher samen. Kant legt Dadrua ceve gevoel van eenheid met het al, waarin wij ons volstrekt afhankelijk weten van God, de basis van de religie. Herrmann stelt nu dat ons vertrouwen in de zedelijke mach van het goede leidt tot de ervaring dat wij in een samenhangende groei van het goede zijn opgenomen. 
Het is voor Herrmann van groot belang dat God een verborgen werkelijkheid is die in deze wereld werkt (Herrmann [1914] 1967). Hoewel God bovennatuurlijk is, hebben wij met een werkelijkheid van God buiten deze wereld niets te maken en kunnen wij die ook niet poneren. Wij kunnen van God alleen maar zeggen wat hij aan ons doet en hij werkt op ons in als Jezus een Erlebnis voor ons wordt waardoor wij de werkelijkheid van God ervaren als de macht van het goede. God onthult zich in datgene wat zijn openbaring in Jezus aan ons doet. Daardoor wordt hij voor ons een beleefbare werkelijkheid die we moeten onderscheiden van de natuur als bewijsbare werkelijkheid. Daarmee wordt een zeker dualisme geïntroduceerd, omdat de bewijsbare werkelijkheid de hele werkelijkheid niet kan zijn, maar tegelijkertijd wordt vermeden dat Gods werkelijkheid tegenover onze werkelijkheid komt te staan, omdat hij in deze wereld op ons inwerkt. In dit verband noemt Herrmann het wonder (Herrmann [1908] 1967). Het wonder is geen directe ingreep van God in de natuur waardoor iets tegennatuurlijks gebeurt. Het wonder is juist dat een natuurlijke gebeurtenis als bewijsbare werkelijkheid tegelijkertijd als beleefbare werkelijkheid een daad van God is, zonder dat die twee onder één gezichtspunt te verenigen zijn. ${ }^{3}$

Herrmanns theologie wordt gekleurd door een 19e-eeuws vooruitgangsoptimisme. Hoewel de natuur is onderworpen aan de natuurwetmatigheid, geloven wij dat God daarin op een verborgen wijze werkzaam is en deze wereld ten goede leidt. Wij kunnen God niet bewijzen of beschrijven, maar wel beleven aan de manier waarop hij op ons inwerkt, voornamelijk door het innerlijke leven van Jezus. Daarin ligt een empirische grond om de doelmatigheid van de wereld als geloofsvoorstelling te handhaven, waardoor wij gericht kunnen zijn op het ver voor ons liggende einddoel van autonome individuen die met elkaar tot een gemeenschap verenigd zijn.

\section{Rudolf Bultmann}

In de eerste helft van de 20e eeuw liet Bultmann het optimisme van de liberale theologie achter zich (Schmithals 1966; Hammann 2009). 'God' heeft niet te maken met de macht van het goede in deze wereld, maar met het oordeel over deze wereld die in de crisis ligt. Bultmann bleef echter trouw aan Herrmann in zijn opvatting dat wij God niet mogen objectiveren, maar alleen leren kennen in wat hij aan ons doet. Anders dan bij Herrmann werkt God echter niet op ons in door het innerlijke leven van Jezus, maar door de verkondiging van kruis en opstanding. Daardoor worden wij aan de 'beschikbare' wereld ontheven en kunnen we 'eigenlijk' leven. Dat is gedacht in het spoor van Heidegger. Het handelen van God wordt daardoor niet langer teleologisch, maar existentieel en eschatologisch opgevat. De

\footnotetext{
3. Het zou volgens Herrmann beslist onjuist zijn om de openbaring van God in de beleefbare werkelijkheid subjectief te noemen, omdat ze teruggaat op de aanblik van Jezus' persoonlijke leven waarin het geloof zijn objectieve grond vindt. He zou ook onjuist zijn om de beleving van Gods werkelijkheid te zien als dichterlijke fantasie, een mystiek gevoel, of de duistere voorstelling van een oneindigheid waarin wij kunnen verzinken. Dat kun je, met Hume en Feuerbach, projecti noemen. De openbaring van God in de beleefbare werkelijkheid is onlosmakelijk verbonden met de zedelijkheid en die vormt volgens Kant geen projectie, maar een bovennatuurlijke werkelijkheid.
}

doelmatigheid van de wereld en haar ontwikkeling spelen geen rol meer, omdat de wereld al aan haar einde gekomen is als God zich door kruis en opstanding aan ons openbaart en ons daardoor een nieuwe zijnswijze geeft. Bultmanns opvattingen over (1) de niet-objectiveerbare kennis van God, (2) door kruis en opstanding, waardoor wij (3) nieuw leven buiten de beschikbare wereld, vragen om een korte toelichting voordat wij hem met Herrmann en Kaufman kunnen vergelijken.

Bultmann volgde Herrmann in zijn opvatting dat wij van God alleen maar kunnen zeggen wat hij aan ons doet. God is de almachtige, alles bepalende werkelijkheid. Wij kunnen daar echter niet objectiverend over spreken, omdat wij zelf door die werkelijkheid worden bepaald. Als wij over God spreken, moeten wij dus over onszelf spreken en over de manier waarop wij door God bepaald worden, maar dan spreken wij over onszelf en niet over God en daarmee doen we geen recht aan God die als de 'Geheel Andere' van ons en onze werkelijkheid verschilt. Dat God als almachtige de 'Geheel Andere' is, wil niet zeggen dat wij hem buiten de wereld kunnen lokaliseren of metafysisch moeten denken. God is als de almachtige, alles bepalende werkelijkheid de Geheel Andere die ook mij bepaalt, waarover ik nooit los van mijzelf kan spreken, maar die toch heel anders is dan ik (Bultmann [1925] 1933).

Het is wonderlijk dat wij überhaupt iets van God kunnen weten, want God is niet zichtbaar, niet beschikbaar en niet uit de wereld afleidbaar. Normaal gesproken leven wij in een beschikbare, voorhanden, geobjectiveerde wereld die bepaald wordt door de natuurwetmatigheid. Daarin proberen wij de gebeurtenissen te overzien om voor ons bestaan te zorgen. Die wereld wordt echter doorbroken als God zichzelf bekend maakt door het wonder, waardoor een gewone gebeurtenis in deze wereld tot een daad van God wordt waarin hij zich openbaart. God maakt zich door een wonder bekend en er is eigenlijk maar één wonder, namelijk dat hij zich bekend maakt in een gewone gebeurtenis die door het geloof wordt gezien als een handeling van God, zonder dat er een directe identiteit bestaat tussen de gebeurtenis en de daad van God als handeling in, met of onder die gebeurtenis (Bultmann 1933a). Door het wonder zien wij dat de beschikbare, causaal bepaalde, natuurkundige wereld niet de hele wereld is en worden wij weggehaald uit de 'oneigenlijke' bestaanswijze in een berekenbare wereld waarin wij voor onszelf zorgen om voortaan 'eigenlijk' te leven. Dat eigenlijke leven is een leven uit genade waarin wij zijn vrijgemaakt van de beschikbare wereld, de zorg om onszelf en ons verleden om te gehoorzamen aan de aanspraak die God op ons maakt (Bultmann [1958] 1965).

Als God zich door het wonder aan mij bekendmaakt, kan ik in het geloof zinvol spreken over God. In dat geval spreek ik echter niet zozeer 'over' God, maar veeleer 'uit' God. Het verschil daartussen kan worden toegelicht door een vergelijking met vriendschap of liefde. Als iemand mij zijn vriendschap biedt, weet ik theoretisch niets extra's over vriendschap en kan ik ook niks toevoegen aan definities of 
beschrijvingen daarvan, maar toch verandert alles, omdat ik nu kan leven uit een vriendschap die ik mag ontvangen. Zo kan ik over God ook alleen 'uit God' spreken. Dat voegt aan het godsbegrip helemaal niets toe, maar leert ons wel om over de werkelijke God te spreken en niet over een godsbegrip. Als wij werkelijk over God spreken, is onze eigen existentie daarbij ingesloten. In dat geval kunnen wij bijvoorbeeld niet objectiverend stellen dat God de werkelijkheid bepaalt, maar slechts zeggen hoe hij ons bepaalt en daarom Heer is, omdat hij ons bepaalt. Wij kunnen van God slechts zeggen wat hij aan ons doet en als wij op grond daarvan over God spreken, moeten wij ook over onszelf spreken. Alleen als wij zelf van de oneigenlijkheid zijn bevrijd, weten we dat we om die reden met Gods almacht van doen hebben en alleen als wijzelf zijn vernieuwd, belijden wij onszelf als schepsel en belijden wij God als Heer, omdat wij dat aan onszelf ervaren en alleen maar over God spreken door uit God over onszelf te spreken (Bultmann [1925] 1933:31 e.v.).

Het wonder van Gods openbaring komt volgens Bultmann niet tot stand door het innerlijke leven van Jezus en daarin onderscheidt hij zich radicaal van Herrmann. Het Nieuwe Testament geeft ons helemaal geen beeld van Jezus' persoonlijkheid of van de 'Christus naar het vlees', waarvan wij niets weten (Bultmann 1933b:249-252). De beleving van Jezus' persoonlijkheid kan illusoir zijn en biedt volstrekt geen zekerheid, omdat andermans geloof, zelfs dat van Jezus, geen enkele basis kan zijn voor ons geloof (Bultmann [1924] 1933:12-13). Wij kunnen ons evenmin tot Jezus verhouden, want hij is er niet meer (Bultmann [1927] 1933:104-106). De openbaring van God is volgens Bultmann daarom niet gelegen in het beeld van Jezus' persoonlijkheid of zijn innerlijke leven, maar in de verkondiging van het kruis. De christelijke boodschap verkondigt ons het kruis en vraagt van ons dat wij onszelf verstaan als zondaren die het kruis op zich nemen om aan het nieuwe leven van Christus' opstanding deel te krijgen (Bultmann 1933c, 1933b:260, [1941] 1985:55-57). De verkondiging van het kruis is als Anrede zelf het heilsgebeuren waarin Christus aanwezig is en God zich openbaart (Bultmann 1933c:289). ${ }^{4}$ In die verkondiging is Christus aanwezig, die geen openbaring is van God door zijn innerlijke leven, maar door het woord van het kruis waarin hij aanwezig is.

Als God zich openbaart, wordt de historische gebeurtenis van het kruis door de verkondiging een daad van God aan mij die mij vernieuwt. Door Gods daad laat ik mij met Christus kruisigen. Die kruisiging wil zeggen dat ik vrijgemaakt word van mijzelf en de bestaansmogelijkheden die mij in de wereld worden aangereikt. Door de kruisiging geeft de gelovige alle binding aan de wereld prijs. Hij doorziet zijn beperkingen en begrensdheid en probeert zichzelf niet meer binnen het wereldse domein te verwerkelijken, omdat het woord van het kruis dat domein heeft geoordeeld en de gelovige daarvan heeft losgemaakt. De gelovige existentie is daarom een eschatologische existentie. Het is een bestaan in de

4.De verkondiging is geen weergave van het heilsgebeuren, maar zelf heilsgebeuren. Bultmann verdedigt die opvatting met de tekst uit 2 Korinthe 5:18-21. Tegelijk met Bultmann verdedigt die opvatting met de tekst uit 2 Korinthe $5: 18-21$. Tegelijk met
het kruis heeft God de dienst der verzoening ingesteld, zodat de verzoening voor het kruis heeft God de dienst der verzoening ingesteld, zodat de verzoening voor
ons samenvalt met de verkondiging die daarom voor ons het heilsgebeuren is. wereld, los van de wereld, waaraan door Christus een einde is gemaakt. Door het kruis wordt de gelovige een nieuwe schepping, bevrijd van de angst en geopend voor de liefde. Daarin toont zich het nieuwe leven van de opstanding, maar daarmee wordt niet het begin van een nieuwe geschiedenis geopend, alsof wij nu, met Herrmann, zouden geloven in zedelijke doeleinden door de kracht van het goede. Dat zou een terugval zijn in het wereldse domein en een ontkenning van de eschatologische existentie. De kern van die existente is dat wij gedistantieerd tegenover de wereld staan. De gelovige leeft in de wereld alsof hij er niet leefde en bezit de wereldse dingen alsof hij ze niet had (1 Kor 7:29-31), omdat de oude wereld door Christus is beëindigd. Juist in de distantie tot de wereld manifesteert zich de vernieuwing (Bultmann [1941] 1954:95-98).

Bultmann benadrukt dat het geloof geen wereldbeschouwing is en geen wereldbeeld biedt, omdat het geen theorie over de wereld bevat, maar wordt gewonnen in het woord van het kruis dat de geschiedenis en alle wereldbeelden beëindigt. Wij kunnen wel een wereldbeeld formuleren waarin de mens afstamt van de apen of bestaat uit verbindingen van atomen en wij kunnen God daarin wel opnemen als principe ter verklaring van de wereld, maar dan hebben wij het over een godsbegrip en niet over de werkelijke God, die zich paradoxaal aan ons openbaart in de gebeurtenis van het kruis (Bultmann [1925] 1933:31-33, 1933a:225). De werkelijkheid van God is een transcendente werkelijkheid die buiten de objectiveerbare en wetenschappelijk onderzoekbare wereld valt. Bultmann wil daarmee echter geen metafysisch dualisme introduceren, want er is maar één werkelijkheid die onder een dubbel aspect kan worden gezien, enerzijds als beschikbare en bestudeerbare wereld, anderzijds als wereld waarin de mens bewogen is door de vraag naar de eigenlijkheid van zijn existentie. In die laatste wereld kan de mens zich geraakt weten door het licht van een transcendente werkelijkheid waardoor hij in zijn bestaan wordt bevraagd en begenadigd (Bultmann 1971). Wat Bultmann daarmee wil aanduiden is wel duidelijk. Gods werkelijkheid is echt, valt niet samen met de objectiveerbare wereld en is in die zin transcendent. Ze vormt echter geen werkelijkheid 'boven' of 'achter' onze werkelijkheid en is niet te traceren, metafysisch te lokaliseren of in objectieve termen te beschrijven. Gods transcendente werkelijkheid is voor ons slechts aanwezig in wat ze aan ons doet en kan daarvan nooit worden losgemaakt.

Met Herrmann deelt Bultmann de opvatting van Gods transcendente werkelijkheid die wij nooit objectief kunnen aanwijzen of beschrijven en waarvan we slechts kunnen zeggen wat zij aan ons doet, waardoor wij altijd ook over onszelf moeten spreken als wij over God spreken. Anders dan bij Herrmann is de doelmatigheid van de wereld echter geen thema meer voor Bultmann. De vraag naar het doel van de wereld en de zin van de geschiedenis zijn oneigenlijke vragen. In een gelovig leven als eschatologische existentie kan ik slechts spreken over de zin van mijn leven door wat er aan mij is geschied in een bevrijding of losmaking van de wereld. 


\section{Gordon Kaufman}

In recente boeken heeft Gordon Kaufman een herziening van christelijke geloofsopvattingen voorgesteld. Hij stelt het moderne, wetenschappelijke wereldbeeld centraal en poneert dat de theologie haar uitgangspunt niet moet nemen in de traditie die dan om een nieuwe interpretatie vraagt, maar moet beginnen bij het moderne wereldbeeld. De bestaande religieuze tradities schieten tekort in hun functie om mensen te oriënteren, omdat ze de evolutie en de opkomst van biohistorische wezens nooit hebben gethematiseerd terwijl die in ons wetenschappelijke wereldbeeld juist centraal zijn komen te staan. De taak van de theologie is daarom niet hermeneutisch, maar constructief (Kaufman 2006:2).

Het wetenschappelijke, evolutionaire wereldbeeld vraagt om een afwijzing van alle dualisme en supranaturalisme. Daarin is Kaufman verwant aan de moderne theologen van de 19e eeuw. Zij veronderstelden echter een wereld die door een gesloten natuurwetmatigheid wordt bepaald. Herrmann en Bultmann braken die gesloten wereld open met de ervaring van God als een verborgen werkelijkheid waardoor Herrmann de zedelijkheid en doelmatigheid in de natuurlijke wereld introduceerde en Bultmann de mens uit de natuurlijke wereld wilde bevrijden tot zijn 'eigenlijkheid'. Kaufman gaat echter uit van een open wereld die niet door de natuurwetmatigheid wordt gedetermineerd, maar door creativiteit open staat voor nieuwe ontwikkelingen. In die wereld moet God niet gedacht worden als de Creator buiten het proces, maar als creativity in het proces. Kaufman lijkt daarmee gedachten van Whitehead, Hartshorne en de procestheologie over te nemen, maar distantieert zich daarvan toch. Met betrekking tot de vraag naar God moet de theologie volgens hem haar eigen werk doen en daarom wil hij zich niet baseren op Whiteheads terminologie en diens conceptualisering van de wereld als proces (Kaufman 1993:46).

De hoofdlijnen van Kaufmans theologie en christelijke wereldbeeld zien er als volgt uit. Mensen zijn voortgebracht door het ecosysteem van de aarde dat door evolutie is ontstaan. Zij leven echter ook in een wereld van waarden, die zij in de geschiedenis zelf organiseren en waarin zij hun eigen doelen bepalen. De opkomst van mensen als zogenaamde bio-historische wezens uit de biologische orde veronderstelt een creatieve activiteit in het wereldproces, die zichzelf uitdrukt in de mens die van die creativiteit afhankelijk is en daaraan ook kan bijdragen (Kaufman 1993:97-234). De scheppingskracht volgt geen blauwdruk, alsof er aan het begin van de kosmos al een plan was dat nu wordt uitgevoerd, maar valt te karakteriseren als serendipitous creativity, dat is een scheppingsdrang die gebruik maakt van het toeval en zich laat leiden door het proces zelf, waarin zich kansen en mogelijkheden voordoen (ibid:264-280). Het creatieve proces laat zich vergelijken met de onvoorziene ontwikkeling van een gesprek, waarin gedachten opkomen die worden besproken, gecorrigeerd of aangevuld, en in de loop van het gesprek aanleiding geven tot nieuwe gedachten. Mensen zijn in zekere zin de toevallige uitdrukking van de scheppende werkzaamheid, maar zelfs dan zijn ze gegrond in de creativiteit als ultieme aard van de werkelijkheid en daarom geen misbaksel of willekeurige speling van de natuur. De creativiteit wekt de indruk van doelgerichtheid, omdat ze zich na de 'Big Bang' een weg lijkt te banen door de kosmische evolutie, de biologische ontwikkelingen en de menselijke activiteiten in cultuur en technologie naar steeds complexer vormen van denken, voelen en gedragen. Dat wil echter niet zeggen dat wij een einddoel kennen of kunnen aannemen. De christelijke eschatologie met haar ultieme toekomstbeelden moet daarom worden geschrapt (Kaufman 2006:58).

Wanneer Kaufman spreekt over de creativiteit, wil hij niets verklaren, maar benoemt hij slechts het mysterie aan de basis van het leven dat wij nooit volledig kunnen doorzien of beschrijven. Als Kaufman deze creativiteit 'God' noemt, wil hij daarmee een kwalitatief onderscheid tussen God en mens handhaven. De scheppende werkzaamheid is van een andere orde dan al het geschapene. Juist vanwege dat verschil is God als creativiteit onze toewijding en verering waardig, zonder het risico dat wij een geschapen werkelijkheid verafgoden en zonder het risico dat wij God antropomorf buiten het proces plaatsen. Daardoor kunnen wij ons 'onder God' in de wereld oriënteren op de creativiteit die zich in steeds wisselende situaties steeds anders presenteert (Kaufman 1993:301-359). Wij weten niet waar God of de creativiteit ons zullen brengen, maar wij vertrouwen ons daaraan toe, zoals de Hebreeërs uit Exodus erop vertrouwden dat de uittocht hen ergens brengen zou. In ons vertrouwen op God of scheppingsdrang weten wij ons verantwoordelijk voor de instandhouding van het leven en de aarde die het resultaat zijn van de scheppingsmacht, zoals wij ons meer in het algemeen verplicht weten aan dat wat God of creativiteit naar onze opvatting op aarde tot stand brengt. Om nader te bepalen wat God op deze aarde tot stand brengt, kan het verhaal van Jezus als norm worden gebruikt (Kaufman 2006:51). Daarin wordt ons een mens gepresenteerd die volstrekt op God vertrouwde en daarom liefdevol, zorgzaam en vergevend omging met alle mensen, zelfs met zijn vijanden. Waarden als liefde, verzoening, vergeving en zelfopoffering voor het welzijn van de mensheid worden geconcretiseerd in het verhaal van Jezus, dat ons daarom iets van God en creativiteit openbaart wat wij anders niet geweten zouden hebben. Het verhaal van Jezus geeft christenen een model voor hun leven en een norm om te bepalen wat werkelijk creatief is. Daaruit volgt ook een indruk van de weg die de scheppingsmacht in de menselijke wereld op aarde inslaat, namelijk de weg van de toenemende humanisering en de liefde. ${ }^{5}$ De creativiteit die God is, wordt door Jezus dus nader en voorbeeldig bepaald.

Kaufmans herformulering van God als creativiteit wordt verregaand bepaald door een zekere pragmatiek. Wij gebruiken het symbool 'God' om het geheel aan te duiden waarin wij leven en ervaringen opdoen. Wij komen God daarom nooit tegen als een object of in een bijzondere

5. Kaufman stelde aanvankelijk dat wij aan Christus kunnen zien, in welke richting de creativiteit in de kosmos (en niet alleen in de mensenwereld) zich ontwikkelt. $\mathrm{Hij}$ verbond Jezus bovendien met een trinitaire opvatting van God. Later liet hij beide opvattingen los; vergelijk Kaufman (1993:412-425 met 2006:54, 55). 
ervaring, omdat wij met het woord 'God' juist het wereldbeeld beschrijven waarbinnen ervaringen eerst optreden (Kaufman 1993:322-343). Dat wereldbeeld is een product van menselijke verbeelding dat wij als een geheel samenstellen uit de fragmenten van onze ervaring en de brokstukken van onze kennis. We stellen dat wereldbeeld vooral op, omdat wij het nodig hebben om ons te oriënteren in de wereld waarin wij moeten handelen. Daarvoor hebben wij een richting nodig en een beeld van waar wij ons bevinden. Wie meent het zonder wereldbeeld te kunnen stellen vergist zich (ibid:345). Door God te reconstrueren als creativiteit wil Kaufman vooral oriëntatie vinden. God als creativiteit sluit beter aan bij het moderne denken dan een God als afzonderlijke, buitenwereldse entiteit, en als menselijk concept brengt het ook wel werkelijkheid in beeld, maar toch is het niet in de eerste plaats bedoeld om een metafysische of ontologische waarheid uit te drukken. Met het concept van God claimen wij geen kennis van hoe of waarom alles is ontstaan, maar geven wij aan dat wij toegewijd willen zijn aan de weg die de scheppingsmacht op aarde is ingeslagen door mensen voort te brengen en in de mensenwereld humanisering en liefde te stimuleren (ibid:346-349). Juist op deze manier biedt het symbool 'God' oriëntatie, omdat we daarmee aangeven aan welke werkelijkheid wij als Gods werkelijkheid toegewijd willen zijn. De formulering van een wereldorde op zichzelf zou ons geen oriëntatie bieden, evenmin als het concept van de evolutie als zodanig. De reconstructie van God als creativiteit oriënteert ons omdat wij daarmee aangeven wat wij met ons leven willen dienen, namelijk die scheppingsdrang die mensen aanspoort zelf verantwoordelijkheid te nemen voor meer humaniteit. Door de lading van het symbool 'God' wordt God zogezegd meer dan alleen een beschrijving van bijvoorbeeld innovativiteit of evolutie omdat wij ons juist door de 'Gold-talk' dienend toewijden aan de creativiteit in de wereld, die zich ook precies in onze creatie van de Goldtalk als creativiteit manifesteert. Door onze toewijding aan de creativiteit kunnen wij moreel kwaad tegengaan dat bestaat in de corruptie van normen, waarden, ideeën en idealen die ons ideologisch verblindt en kunnen wij onszelf behoeden voor het theologische kwaad dat wij onze eigen maatstaf absoluut stellen (ibid:360-373).

\section{Conclusie}

$\mathrm{Na}$ Darwin waren er geen doeloorzaken meer nodig om de natuur te verklaren. Een plan voor de natuur, op grond waarvan God verondersteld kan worden, werd daardoor obsoleet. Kaufman neemt dat inzicht op. Er is geen schepper met een plan buiten de natuur, maar er is creativiteit in het wereldproces, die als het ware het plan voor de schepping vervangt en de basis vormt voor een nieuw religieus wereldbeeld. Hij onderscheidt zich daarmee van Herrmann die uit de religieuze ervaring van het innere Leben Jesu een kader afleidde waarbinnen hij de wereld doelmatig denkt, en van Bultmann voor wie de doelmatigheid van de wereld helemaal geen thema meer was. Kaufman ziet het als de taak van de theologie om een wereldbeeld te formuleren waarmee wij ons in de wereld kunnen oriënteren. Voor Bultmann ging het er juist om dat wij door het woord van het kruis van de wereld en van wereldbeelden worden bevrijd. Dit verschil hangt samen met een verschillende opvatting over de werkelijkheid van God en onze kennis daarvan. Bultmann stelt dat wij de werkelijkheid van God ervaren in de historische gebeurtenis van het kruis die wij in het geloof als een aanspraak van God verstaan. Kaufman meent dat de werkelijkheid van God niet in één gebeurtenis kan worden ervaren, maar in beeld wordt gebracht door de formulering van een wereldbeeld waaraan wij ons kunnen oriënteren. Bultmann en Kaufman willen beiden voorkomen dat God als een metafysische entiteit buiten de wereld wordt gedacht. Bultmann legt daarbij echter nadruk op de werkelijkheid van God die zich in de wereld aan ons meedeelt, Kaufman vreest dat daarmee toch een zeker dualisme tussen God en wereld wordt aangebracht waardoor God alsnog buiten de wereld wordt geplaatst.

In de constructie van zijn wereldbeeld is Kaufman actueler en eigentijdser dan Herrmann en Bultmann. Het natuurlijke inzicht dat wij leven in een wonderlijk en creatief evolutionair proces kan volgens hem het kader leveren voor een nieuwe religieuze houding waarin wij ons bestaan dankzeggend aanvaarden, God toegewijd zijn en verantwoordelijk willen leven. Kaufman laat daarbij echter los wat Herrmann en Bultmann als werkelijkheid van God aanwezen, omdat zij niet zou passen binnen het huidige, wetenschappelijke wereldbeeld dat om strikte immanentie vraagt. Daardoor loopt hij het risico de eigen aard van het geloofsleven te veronachtzamen en te miskennen. Om dit punt te verduidelijken is de wederzijdse kritiek van Kaufman en Bultmann op elkaars positie behulpzaam.

Kaufman wil in zijn theologie nadrukkelijk niet beginnen bij de religieuze ervaring van Jezus' innerlijke leven of de indruk die de verkondiging op ons maakt, zoals Herrmann en Bultmann doen. Die ervaringen vallen namelijk altijd binnen de structuur van een wereldbeeld en worden daardoor bepaald. Het wereldbeeld maakt de ervaring mogelijk, maar kan zelf niet uit ervaringen worden afgeleid (Kaufman 1993:343). Daarom moet de theologie niet beginnen bij de ervaring van Jezus' innerlijke leven of het woord van het kruis, maar met de formulering van een wereldbeeld. Dat is des te dringender nu de religies achterlopen bij wetenschappelijke inzichten. In het wereldbeeld kan 'God' een belangrijk symbool zijn, dat niet illusionair is, maar ook nooit samenvalt met het mysterie van God. Zo kan het concept van 'God' mensen oriënteren zonder dat het zelf wordt verabsoluteerd, omdat ons concept van 'God' altijd onder kritiek van God gesteld kan worden. Zou de werkelijkheid van God zich in één ervaring aandienen, zou deze ervaring alsnog absoluut gesteld worden en zou de werkelijkheid van God transcendent en dualistisch moeten worden opgevat.

Kaufmans grootste bezwaar tegen Bultmann luidt dan ook dat hij blijft steken in een vorm van dualistisch denken. Bultmann

... seems to retain the basic idea of the 'other side' - another reality outside this life, this world of our experience - which is more important than anything on 'this side' since it is the real 
foundation of life and its meaning ... I am proposing that we go much further in our reconception than did Bultmann, and that we refrain from postulating 'another side' or 'another world' at all. (Kaufman 1993:324)

Kaufman heeft geen ongelijk dat Bultmann een zeker dualisme tussen God en wereld blijft erkennen, maar hij miskent dat Bultmann daarmee slechts de onherleidbaarheid van God verdedigt, van wie we alleen maar kunnen zeggen wat hij aan ons doet en die we dus niet in een wereldbeeld kunnen lokaliseren, ook niet 'aan de andere kant'. Er is volgens Bultmann maar één werkelijkheid die echter wel onder een dubbel aspect kan worden beschouwd. Dat neigt misschien naar dualisme, wat door Kaufman wordt afgewezen, maar Kaufman erkent zelf ook een primaire of ultieme dualiteit tussen God en wereld, omdat God nooit gezien kan worden als iets in de wereld of als een deel van de wereld (Kaufman 1993:327). Kaufman wil die dualiteit echter niet verabsoluteren of verzakelijken (reify) en daarom weigert hij beeldspraak te gebruiken die God aan gene zijde plaatst, om daarmee niet de suggestie te wekken dat God kan worden gefixeerd buiten of boven de wereld. Het feitelijke verschil met Bultmann is dan echter slechts gering.

Van zijn kant zou Bultmann Kaufman verwijten dat hij een godsbeeld ontwerpt terwijl het geloof daar helemaal niet mee te maken heeft (Bultmann 1928:115). In het geloof weten wij ons aangesproken door de Anrede van God en kunnen we 'uit' God leven zonder dat we 'over' God extra kennis krijgen om een godsbeeld te ontwerpen. Bultmann zou de werkelijkheid van God beklemtonen, waar Kaufman zich vooral toelegt op de constructie van een godsbeeld. Toch is ook dat verschil niet absoluut. Bultmann kan niet zonder een godsbeeld en beschrijft dat feitelijk ook wanneer hij God beschrijft als de almachtige, alles bepalende werkelijkheid die tegelijkertijd de Geheel Andere is. Kaufman erkent van zijn kant ook wel zoiets als de Anrede van God, als hij schrijft dat wij moeten antwoorden op de creativiteit die zich toont in de situatie waarin we ons bevinden, omdat wij haar - met de antropomorfe woorden van Richard Niebuhr - kunnen verstaan als Gods bedoeling die aanwezig is in, boven en door alle eindige bedoelingen (Kaufman 2006:8-9).

De verschillen tussen Bultmann en Kaufman zijn bij nader inzien niet zo heel erg groot, maar worden vooral bepaald door hun verschillende vertrekpunt. Bultmann begint bij de ervaring dat wij door God worden aangesproken in de verkondiging van het kruis. Daardoor wordt God een werkelijkheid voor ons waaruit wij kunnen leven, maar die we niet kunnen objectiveren, beschrijven of onderbrengen in enig wereldbeeld. Kaufman begint bij de formulering van een wereldbeeld dat hij beslist wil vrijhouden van dualisme en supranaturalisme om aan te sluiten bij het moderne, wetenschappelijke denken.

Naar mijn mening is er geen bezwaar om God, met Kaufman, als creativiteit te zien. Ook dan blijft naar mijn idee echter gelden dat God voor ons pas een beleefbare werkelijkheid wordt als hij ons geeft om nieuw en vernieuwend te leven. Alleen in dat geval leert het christendom ons om werkelijk creatief met God of uit God te leven en is godsdienst meer dan alleen de constructie van een wereldbeeld of een levensbeschouwing. De creativiteit van God wordt in het christelijk geloof uitgedrukt in de uitspraken dat God ons schept en herschept. Als God op ons inwerkt door ons te herscheppen, komen wij niet tot betere kennis van God, maar leren wij werkelijk leven uit God. In dat geval is God een werkelijkheid in het geloofsleven waarvan we kunnen zeggen dat Hij ons heeft gemaakt en nieuw gemaakt, bijvoorbeeld door vergeving van zonden, door de deelname aan Christus of door nieuw opstandingsleven. In het geloofsleven wordt 'God' beleefd als een werkelijkheid, omdat hij creatief scheppend en herscheppend - aan ons doet.

Met deze bewering wordt geen dualisme geïntroduceerd, zoals Kaufman aan Bultmann verwijt, maar worden het geloofsleven en de taal waarin het zich uitdrukt juist serieus genomen en niet op voorhand gereduceerd om te passen bij een wetenschappelijk wereldbeeld. Het is volgens mij ook niet overtuigend om een wereldbeeld te ontwerpen rond het symbool 'God', zoals Kaufman wil, als er in het geloofsleven geen verhouding is tot God waarin God een werkelijkheid wordt. In het geloof is er een verhouding tot God zonder dat God daarom moet worden geobjectiveerd of tegenover de wereld gesteld moet worden. Anderzijds is het echter ook niet overtuigend om de werkelijkheid van God te isoleren van ieder wereldbeeld zoals Bultmann doet. Het wordt in dat geval niet meer duidelijk wat God nog met de wereld te maken heeft. Herrmann geeft geen objectief argument als hij de doelmatigheid van de wereld uit de geloofservaring wil afleiden. Bultmann geeft daarop een overreactie als hij het geloof helemaal los wil maken van ieder wereldbeeld en de gelovige daarmee buiten de wereld plaatst.

De verschillen tussen Kaufman en Bultmann ontstaan doordat zij verschillend inzetten bij het wetenschappelijke wereldbeeld of bij de verkondiging en het geloofsleven. Die twee zijn niet ineen te schuiven of in dezelfde taal uit te drukken, maar daartoe bestaat ook geen noodzaak. Wanneer wij God echter zien als creativiteit, zoals Kaufman zijn godsen wereldbeeld ontwerpt, is de werkelijkheid van God, van wie we alleen maar kunnen zeggen wat hij aan ons doet, daarmee verenigbaar. God wordt een werkelijkheid door wat hij in zijn creativiteit aan mij doet en die ervaring past bij de wereld die zich met een immanente creativiteit ontwikkelt. Uit het geloof hoeft geen doelmatig wereldbeeld te worden afgeleid zoals bij Herrmann. Uit angst voor dualisme en supranaturalisme hoeft de werkelijkheid van God in het geloofsleven niet te worden ontkend zoals bij Kaufman. Evenmin staat de werkelijkheid van God tegenover het wereldbeeld zoals bij Bultmann. De creativiteit in het wereldproces en de werkelijkheid van God die herscheppend op ons inwerkt zijn niet in één blik te vangen, maar evenmin incompatibel.

\section{Tegenstrijdige belangen}

De auteur verklaart geen financiële of persoonlijke belangen te hebben die hem ongepast kunnen hebben beïnvloed bij het schrijven van dit artikel. 


\section{Literatuurverwijzingen}

Benjamins, R., 2008, Een en Ander: De traditie van de moderne theologie, Kok Kampen.

Berkhof, H., 1985, 200 Jahre Theologie: Ein Reisebericht, Neukirchener Verlag, Neukirchen-Vluyn.

Bultmann, R., 1924, 'Die liberale Theologie und die jüngste theologische Bewegung', in Glauben und Verstehen I, Gesammelte Aufsätze 1933, pp. 1-25, Mohr, Tübingen.

Bultmann, R., 1925, 'Welchen Sinn hat es, von Gott zu reden?', in Glauben und Verstehen I, Gesammelte Aufsätze 1933, pp. 26-37, Mohr, Tübingen.

Bultmann, R., 1927, 'Zur Frage der Christologie', in Glauben und Verstehen I, Gesammelte Aufsätze 1933, pp. 85-113, Mohr, Tübingen.

Bultmann, R., 1928, “Die Bedeutung der "dialektischen Theologie" für die neutestamentliche Wissenschaft', in Glauben und Verstehen I, Gesammelte Aufsätze 1933, pp. 114-133, Mohr, Tübingen.

Bultmann, R., 1933a, 'Zur Frage des Wunders', in Glauben und Verstehen I, Gesammelte Aufsätze 1933, pp. 214-228, Mohr, Tübingen.

Bultmann, R., 1933b, 'Die Christologie des Neuen Testaments', in Glauben und Verstehen I, Gesammelte Aufsätze 1933, pp. 245-267, Mohr, Tübingen.

Bultmann, R., 1933c, 'Der Begriff des Wortes Gottes im Neuen Testament', in Glauben und Verstehen I, Gesammelte Aufsätze 1933, pp. 268-293, Mohr, Tübingen.

Bultmann, R., 1941a, 'Die Frage der natürlichen Offenbarung', in Glauben und Verstehen II, Gesammelte Aufsätze 1954, pp. 79-104, Mohr, Tübingen.

Bultmann, R., [1941b] 1985, Neues Testament und Mythologie: Das Problem der Entmythologisierung der neutestamentlichen Verkündigung, 2e Aufl., Kaiser, München. PMid:2981472, PMCid:1887841

Bultmann, R., 1958, 'Jesus Christus und die Mythologie', in Glauben und Verstehen IV Gesammelte Aufsätze 1965, pp. 141-189, Mohr, Tübingen.

Bultmann, R., 1971, 'Die protestantische Theologie und der Atheismus', Zeitschrift für Theologie und Kirche 68, 376-380.
Chalamet, C., 2005, Dialectical theologians: Wilhem Herrmann, Karl Barth and Rudolf Bultmann, Theologischer Verlag, Zürich.

Hammann, K., 2009, Rudolf Bultmann: Eine Biographie, Mohr Siebeck, Tübingen. PMCid:2920678

Haught, J.F., 2000, God after Darwin: A theology of evolution, Westview Press, Boulder. Haught, J.F., 2007, Christianity and science: Toward a theology of nature, Orbis Books, Maryknoll.

Herrmann, J.G.W., [1886] 1921, Der Verkehr des Christen mit Gott: Im Anschluss an Luther dargestellt, 7e druk, Mohr, Tübingen.

Herrmann, J.G.W., [1901] 1904 , Ethik, 3e druk, herdruk 2006, Elibron Classics, Leipzig.

Herrmann, J.G.W., [1908] 1967, 'Der Christ und das Wunder', in P. Fischer-Appelt (red.), Wilhelm Herrmann: Schriften zur Grundlegung der Theologie Teil II, pp. 170-205, Kaiser, München.

Herrmann, J.G.W., [1914] 1967, 'Die Wirklichkeit Gottes', in P. Fischer-Appelt (red.), Wilhelm Herrmann: Schriften zur Grundlegung der Theologie Teil II, pp. 290-317, Kaiser, München.

Jonas, H., 1994, Das Prinzip Leben, Suhrkamp, Frankfurt am Main, first published as Jonas, H., 1973, Organismus und Freiheit: Ansätze zu einer philosophischen Biologie, Vandenhoeck \& Ruprecht, Göttingen.

Kaufman, G.D., 1993, In face of mystery: A constructive theology, Harvard University Press, Cambridge, MA/London.

Kaufman, G.D., 2006, Jesus and creativity, Fortress Press, Minneapolis.

Leeuwenburgh, B., 2009, Darwin in domineesland, Vantilt, Nijmegen.

Peters. T. \& Hewlett, M., 2003, Evolution from creation to new creation: Conflict, conversation and convergence, Abingdon Press, Nashville.

Schmithals, W., 1966, Die Theologie Rudolf Bultmanns: Eine Einführung, Mohr, Tübingen.

Smedes, T., 2009, God én Darwin: Geloof kan niet om evolutie heen, Nieuw Amsterdam, Amsterdam. PMid:19806740 